\title{
Bioremediation of Diesel Fuel by Fungal Consortium Using Statistical Experimental Designs
}

\author{
Khaled M. Ghanem ${ }^{1,2 *}$, Saleh M. Al-Garni ${ }^{2}$, Majid A. Al-Zahrani ${ }^{2}$ \\ ${ }^{1}$ Botany and Microbiology Department, Faculty of Science, Alexandria Univ., \\ Alexandria, Egypt \\ ${ }^{2}$ Biological Sciences Department, Faculty of Science, King Abdulaziz Univ., Jeddah, \\ Saudi Arabia
}

Received: 16 March 2015

Accepted: 5 May 2015

\begin{abstract}
The ability of different local fungal isolates to degrade diesel fuel in liquid medium was studied. The results showed that the percent of diesel degradation varied among the different tested fungi and that $92-100 \%$ of diesel was degraded after 7 days in presence of $0.2 \%(\mathrm{v} / \mathrm{v})$ of tween 80 . The degradation process by A. ustus and A. alternata was significantly influenced by the incubation period, and 7 days of incubation was sufficient for complete diesel degradation. As the diesel fuel concentration increased up to $6 \%(\mathrm{v} / \mathrm{v})$, more than $75 \%$ was degraded by the two strains. The degradation process was enhanced using fungal consortium of A. alternata and A. ustus at different inoculum sizes and elevated surfactant (tween 80) levels. Statistical experimental designs were used to optimize the process of diesel degradation by the fungal consortium. Under optimized medium compositions and culture conditions, overwhelming degradation increase (100\%) for $4 \mathrm{~mL}$ of diesel $/ 25 \mathrm{~mL}$ medium $(16 \%, \mathrm{v} / \mathrm{v})$ was recorded. Optimal conditions obtained in this work provided a solid foundation for further use of the fungal consortium (A. alternata and A. ustus) in treatment of diesel polluted soil. The consortium under the optimized conditions efficiently degraded diesel polluted soil, $12.5 \%(\mathrm{v} / \mathrm{w})$, after 35 days of incubation.
\end{abstract}

Keywords: diesel degradation, fungal consortium, A. alternata and A. ustus, statistical optimization, Plackett-Burman, response surface methodology

\section{Introduction}

The excessive use of petroleum hydrocarbons, as the most important source of energy for life, has had a hazardous effect on the environment and life, which has resulted in global environmental pollution $[1,2]$. Spills of used motor oils such as diesel fuel has led to contamination of soil with hydrocarbons, resulting in serious hazardous

*e-mail: kmghanem@yahoo.com effects to human health, and caused organic pollution of groundwater, which has limited its use. These lead to economic loss and environmental problems [3, 4]. So diesel contamination treatment is an important issue [5].

Traditional methods of cleaning oil pollution are confined to physical and chemical processes. These methods are expensive, time-consuming, and less effective [6]. Biological methods can have the edge over these treatments in removing oil spills. Bioremediation technology is a safe, economical, more efficient, reliable 
method that is harmless and ecofriendly $[4,7,8]$. The principle of bioremediation or the microbial degradation process is about using microbes to destroy hazardous contaminants and convert them to harmless products [2, 9-12]. Many microorganisms such as bacteria, fungi, and yeast use their enzymatic activity to utilize hydrocarbons as a sole carbon source $[8,13,14]$. Fungi have advantages over other microorganisms in that they produce classes of enzymes that can interact with several types of polycyclic aromatic hydrocarbons with a fairly high degree of non-specific activity. Fungi are also tolerant to high concentrations of recalcitrant compounds and are able to flourish in extreme conditions. Some recent studies have been reported to use a mixed population of fungal strains that could enhance biodegradation efficiency, especially on high concentrations of oil $[2,14]$.

The Statistical designs, such as the Plackett-Burman design and response surface methodology (RSM) can enhance biodegradation efficiency by optimizing all the affecting parameters at once, which is better than optimizing one parameter. Plackett-Burman design provides a fast and effective way to identify the important factors among a large number of variables, thereby saving time and maintaining convincing information on each parameter. RSM helps evaluate the important factors and building models to study the interactions between the variables or desirable responses $[15,16]$.

The aim of this study is to degrade diesel fuel by locally isolated fungi under the influence of some cultural conditions of incubation period and different levels of both diesel and surfactant. To enhance the biodegradation process a fungal consortium of A. alternata and A. ustus was used. Thereafter, statistical designs of Plackett-Burman and RSM were used to optimize medium compositions and cultural conditions. The biodegradation of dieselpolluted soil was also done by the fungal consortium.

\section{Materials and Methods}

\section{Chemicals}

Diesel fuel was obtained from the Aramco Company, tween 80 (Sigma Ultra), and n-hexane 85\% HPLC/ SPECTRO reagent (Tedia). Ingredients of media were all analytical grade obtained from recognized chemical suppliers.

\section{Fungal Isolates}

The molds tested for diesel biodegradation were isolated from diesel-contaminated soil at the Industrial Region in South Jeddah city, Saudi Arabia, using potato dextrose agar (PDA), Sabouraud dextrose agar, and Czapek's agar media fortified with streptomycin $[50 \mathrm{mg} / \mathrm{L}]$ to prevent bacterial growth [17]. The fungal species were purified by the single-spore isolation technique and identified using their cultural and morphological characteristics [18-20] as Alternaria alternata, Aspergillus flavus, A. fumigatus, A. niger, A. ustus, Penicillium corylophilum, P. fellutanum, and Rhizopus rhizodopodiformis.

\section{Inoculum and Cultivation}

Spore suspension was prepared from test molds grown on PDA slants for five days at $30^{\circ} \mathrm{C}$ by washing the culture slant with $5 \mathrm{~mL}$ sterilized mineral salt solution $[\mathrm{g} / \mathrm{L}]$ : $\mathrm{NaCl}, 10.0 ; \mathrm{MgSO}_{4} .7 \mathrm{H}_{2} \mathrm{O}, 0.42 ; \mathrm{KCl}, 0.29 ; \mathrm{KH}_{2} \mathrm{PO}_{4}, 0.83$; $\mathrm{Na}_{2} \mathrm{HPO}_{4}, 1.25$; and $\mathrm{NaNO}_{3}, 0.42$; and vortexes for $1 \mathrm{~min}$ [21]. Spore number was counted by a haemocytometer, and a count of approximately $1.6 \times 10^{6}$ spores $/ \mathrm{mL}$ was used to inoculate $50 \mathrm{~mL}$ of the basal minimal salt medium of Bushnell-Haas, which contained $[\mathrm{g} / \mathrm{L}]: \mathrm{MgSO}_{4} \cdot 7 \mathrm{H}_{2} \mathrm{O}$, $0.2 ; \mathrm{CaCl}_{2}, 0.02 ; \mathrm{KH}_{2} \mathrm{PO}_{4}, 1.0 ;\left(\mathrm{NH}_{4}\right)_{2} \mathrm{HPO}_{4}, 1.0 ; \mathrm{KNO}_{3}$, 1.0; $\mathrm{FeCl}_{3}, 0.05$; and $\mathrm{pH}=5.6$ [22]; and dispensed in $250 \mathrm{~mL}$ Erlenmeyer flasks. The media were sterilized by autoclaving at $121^{\circ} \mathrm{C}$ for $15 \mathrm{~min}$, after cooling; under aseptic conditions, a stock diesel fuel sterilized by filtration using a $0.22 \mu \mathrm{m}$ syringe filter was added to the medium at the desired level. Thereafter, the desired level of tween 80 (sterilized by syringe filter) was separately added. The flasks were incubated in a shaking incubator (150 rpm) at $30^{\circ} \mathrm{C}$ for seven days [23]. Inoculum-free flasks were prepared to monitor abiotic loss of diesel. The medium composition was modified according to the statistical experimental designs.

\section{Determination of Residual Diesel}

Following the incubation periods, residual diesel was extracted from the medium with $50 \mathrm{~mL}$-hexane and the process was repeated three times. The extract was evaporated under vacuum using rotator evaporator [Buchi] to $50 \mathrm{~mL}$ volume. Thereafter, the $\mathrm{n}$-hexane extract was estimated for the presence of diesel using gas chromatography [GC] by injecting $1 \mu \mathrm{L}$ of the extract [24].

Gas chromatography [Varian GC-3800] was used for detection of diesel. The GC-3800 was supplied with 1177 injector, FID detector, and capillary column (25 m long, $0.25 \mathrm{~mm}$ ID, $25 \mu \mathrm{m}$ film thickness). The temperature of the injection port and detector was set to $260^{\circ} \mathrm{C}$ and $390^{\circ} \mathrm{C}$, respectively, while the oven temperature was kept constant at $40^{\circ} \mathrm{C}$ for $5 \mathrm{~min}$ and was programmed to increase with a rate of $15^{\circ} \mathrm{C} / \mathrm{min}$ to reach $240^{\circ} \mathrm{C}$ [25].

The degradation percentage was determined according to [26]. This was calculated by subtracting the residual diesel after treatment from the diesel content of untreated sample and divided by the diesel of the untreated sample multiplied by one-hundred.

\section{Biodegradation of Diesel by Fungal Isolates}

The fungal isolates were cultivated in $50 \mathrm{~mL}$ aliquots of Bushnell-Haas broth fortified with $0.2 \%$ [v/v] tween 80 and $1 \%[\mathrm{v} / \mathrm{v}]$ diesel fuel. After incubation, the residual diesel fuel was estimated by GC. 
Table 1. Plackett-Burman experimental design for seven factors and 10 trials.

\begin{tabular}{|c|c|c|c|c|c|c|c|c|c|}
\hline \multirow{2}{*}{ Trial } & \multicolumn{7}{|c|}{ Independent Variables } & \multirow{2}{*}{ D[\%] } & \multirow{2}{*}{ DR[mL/day $]$} \\
\cline { 2 - 10 } & $\mathrm{NH}$ & $\mathrm{CC}$ & $\mathrm{KP}$ & $\mathrm{MS}$ & $\mathrm{KN}$ & $\mathrm{FC}$ & $\mathrm{MV}$ & \\
\hline 1 & {$[-1] 0.1$} & {$[+1] 0.04$} & {$[+1] 2.0$} & {$[+1] 2.0$} & {$[-1] 0.5$} & {$[-1] 0.025$} & {$[-1] 25$} & 95.00 & 0.54 \\
\hline 2 & {$[+1] 0.4$} & {$[-1] 0.01$} & {$[-1] 0.5$} & {$[+1] 2.0$} & {$[+1] 2.0$} & {$[-1] 0.025$} & {$[-1] 25$} & 83.25 & 0.48 \\
\hline 3 & {$[+1] 0.4$} & {$[-1] 0.01$} & {$[+1] 2.0$} & {$[-1] 0.5$} & {$[-1] 0.5$} & {$[+1] 0.1$} & {$[-1] 25$} & 91.50 & 0.52 \\
\hline 4 & {$[-1] 0.1$} & {$[+1] 0.04$} & {$[-1] 0.5$} & {$[-1] 0.5$} & {$[+1] 2.0$} & {$[+1] 0.1$} & {$[-1] 25$} & 98.60 & 0.56 \\
\hline 5 & {$[+1] 0.4$} & {$[+1] 0.04$} & {$[-1] 0.5$} & {$[-1] 0.5$} & {$[-1] 0.5$} & {$[-1] 0.025$} & {$[+1] 75$} & 88.75 & 0.51 \\
\hline 6 & {$[-1] 0.1$} & {$[-1] 0.01$} & {$[+1] 2.0$} & {$[-1] 0.5$} & {$[+1] 2.0$} & {$[-1] 0.025$} & {$[+1] 75$} & 85.00 & 0.49 \\
\hline 7 & {$[-1] 0.1$} & {$[-1] 0.01$} & {$[-1] 0.5$} & {$[+1] 2.0$} & {$[-1] 0.5$} & {$[+1] 0.1$} & {$[+1] 75$} & 97.00 & 0.55 \\
\hline 8 & {$[+1] 0.4$} & {$[+1] 0.04$} & {$[+1] 2.0$} & {$[+1] 2.0$} & {$[+1] 2.0$} & {$[+1] 0.1$} & {$[+1] 75$} & 90.40 & 0.52 \\
\hline $9[$ basal medium $]$ & {$[0] 0.2$} & {$[0] 0.02$} & {$[0] 1.0$} & {$[0] 1.0$} & {$[0] 1.0$} & {$[0] 0.05$} & {$[0] 50$} & 95.50 & 0.54 \\
\hline 10 & {$[-1] 0.1$} & {$[-1] 0.01$} & {$[-1] 0.5$} & {$[-1] 0.5$} & {$[-1] 0.5$} & {$[-1] 0.025$} & {$[-1] 25$} & 82.60 & 0.47 \\
\hline
\end{tabular}

$\left(\mathrm{NH}_{4}\right)_{2} \mathrm{HPO}_{4}(\mathrm{NH}), \mathrm{CaCl}_{2}(\mathrm{CC}), \mathrm{KH}_{2} \mathrm{PO}_{4}(\mathrm{KP}), \mathrm{MgSO}_{4} \cdot 7 \mathrm{H}_{2} \mathrm{O}(\mathrm{MS}), \mathrm{KNO}_{3}(\mathrm{KN}), \mathrm{FeCl}_{3}(\mathrm{FC})$, Medium volume/flask [mL] $[\mathrm{MV}]$, Degradation \% [D \%], Degradation rate [DR, $\mathrm{mL} /$ day].

Time Course Biodegradation of $1 \%$ Diesel Fuel by Fungal Consortium of $A$. ustus and $A$. alternata

To minimize the degradation period for maximum degradation of diesel, the most two potent fungi with the highest degradation efficiency (A. alternata and A. ustus) were inoculated into $50 \mathrm{~mL}$ aliquots of the basal medium fortified with $1 \%[\mathrm{v} / \mathrm{v}]$ of diesel fuel and $0.2 \%[\mathrm{v} / \mathrm{v}]$ tween 80 . The batch cultures were incubated at different fermentation periods. Thereafter, the residual diesel fuel was estimated every 24 hours (after the first 96 hours of incubation) up to 192 hours (eight days) of degradation.

\section{Biodegradation of Different Concentrations of Diesel Fuel by Fungal Consortium with Different Spore Numbers}

Fungal consortium of the most potent mold (A. alternata) for diesel degradation and $A$.ustus (the second most efficient) was used to degrade different diesel concentrations (1, 2, 3, $4,5$, and $6 \%, \mathrm{v} / \mathrm{v})$ at different inoculum sizes $(1.6,2.4$, and $3.2 \times 10^{6}$ spores $\left./ \mathrm{mL}, 1: 1\right)$. The batch culture was incubated under the same conditions and the residual diesel was estimated after seven days of fermentation.

\section{Effect of Different Levels of the Surfactant (Tween 80) on Diesel Biodegradation}

To test the effect of different levels of the surfactant (tween 80 ) on the efficiency of the mixed culture to degrade diesel fuel, $50 \mathrm{~mL}$ of the basal medium were fortified with different levels of tween $80(0.0,0.2,2.0,4.0$, and $6 \%$, $\mathrm{v} / \mathrm{v}$ ), and tested to degrade 3 and $4 \mathrm{~mL}$ of diesel. Inoculum size of $3.2 \times 10^{6}$ spores (the best Inoculum) of A.ustus and A.alternata (1:1) was used.

\section{Experimental Designs}

Plackett-Burman Design

Plackett-Burman is an efficient way to identify the important factors among a large number of variables [27]. It was used to screen the important variables that significantly influenced diesel degradation. In this study, a 10-run Plackett-Burman design [28] was applied to evaluate seven factors. Each variable was examined at two levels: -1 for the low level and +1 for the high level (Table 1). All trials were performed in duplicate and the averages of degradation observation results were treated as responses. The main effect of each variable was determined with the following equation:

$$
\mathrm{E}_{\mathrm{xi}}=\left(\Sigma \mathrm{M}_{\mathrm{i}+}-\Sigma \mathrm{M}_{\mathrm{i}-}\right) / \mathrm{N}
$$

... where $\mathrm{E}_{\mathrm{xi}}$ is the variable main effect; $\mathrm{M}_{\mathrm{i}_{+}}$and $\mathrm{M}_{\mathrm{i}-}$ are the diesel degradation percentages in trials where the independent variable [xi] was present in high and low concentrations, respectively; and $\mathrm{N}$ is the number of trials divided by 2 . The main effect figure with a positive sign indicates that a high concentration of this variable is nearer to optimum and a negative sign indicates that the low concentration of this variable is nearer to optimum. Using Microsoft Excel, statistical $t$-values for equal unpaired samples were calculated to determine variable significance.

\section{Response Surface Methodology (RSM)}

In order to describe the nature of response surface in the experimental region and to elucidate the optimal concentrations of the most significant independent variables, a Box-Behnken design [29] was applied, which 
Table 2. Box-Behnken design for the most significant three variables that affected diesel biodegradation by fungal consortium of $A$. ustus and $A$. alternata.

\begin{tabular}{|c|c|c|c|c|c|}
\hline \multirow[t]{2}{*}{ Trial } & \multicolumn{3}{|c|}{ Variables $[\mathrm{g} / \mathrm{L}]$} & \multirow{2}{*}{$\mathrm{D}[\%]$} & \multirow{2}{*}{$\begin{array}{c}\text { DR } \\
{[\mathrm{mL} / \mathrm{day}]}\end{array}$} \\
\hline & $\mathrm{A}\left(\mathrm{CaCl}_{2}\right)$ & $\mathrm{B}\left(\mathrm{FeCl}_{3}\right)$ & $\left.\mathrm{C}\left(\left(\mathrm{NH}_{4}\right)_{2} \mathrm{HPO}_{4}\right)\right)$ & & \\
\hline 1 & {$[-1] 0.0$} & {$[-1] 0.00$} & {$[-1] 0.0$} & 77.20 & 0.44 \\
\hline 2 & {$[-1] 0.0$} & {$[0] 0.01$} & {$[+1] 4.0$} & 97.75 & 0.56 \\
\hline 3 & {$[-1] 0.0$} & {$[+1] 0.02$} & {$[0] 2.0$} & 95.75 & 0.55 \\
\hline 4 & {$[0] 0.04$} & {$[-1] 0.00$} & {$[+1] 4.0$} & 94.25 & 0.54 \\
\hline 5 & {$[0] 0.04$} & {$[0] 0.01$} & {$[0] 2.0$} & 98.60 & 0.56 \\
\hline 6 & {$[0] 0.04$} & {$[+1] 0.02$} & {$[-1] 0.0$} & 98.30 & 0.56 \\
\hline 7 & {$[+1] 0.08$} & {$[-1] 0.00$} & {$[0] 2.0$} & 97.80 & 0.56 \\
\hline 8 & {$[+1] 0.08$} & {$[0] 0.01$} & {$[-1] 0.0$} & 87.80 & 0.50 \\
\hline 9 & {$[+1] 0.08$} & {$[+1] 0.02$} & {$[+1] 4.0$} & 100 & 0.57 \\
\hline
\end{tabular}

Degradation \% [D \%], Degradation rate [DR, $\mathrm{mL} /$ day].

is an RSM. As presented in Table 2, factors of highest MV confidence levels, namely; $\mathrm{CaCl}_{2}$ (A), $\mathrm{FeCl}_{3}$ (B), and $\left(\mathrm{NH}_{4}\right)_{2} \mathrm{HPO}_{4}(\mathrm{C})$ were tested in three levels (low, basal, and high) coded $-1,0$, and +1 . Accordingly, nine diesel treatment combinations were executed. For predicting the optimal point, the following second-order polynomial model was fitted to correlate the relationship between the independent variables and the response:

$$
\begin{gathered}
\mathrm{Y}=\mathrm{b}_{0}+\mathrm{b}_{1} \mathrm{~A}+\mathrm{b}_{2} \mathrm{~B}+\mathrm{b}_{3} \mathrm{C}+\mathrm{b}_{12} \mathrm{AB}+\mathrm{b}_{13} \mathrm{~A} \\
\mathrm{C}+\mathrm{b}_{23} \mathrm{BC}+\mathrm{b}_{11} \mathrm{~A}^{2}+\mathrm{b}_{22} \mathrm{~B}^{2}+\mathrm{b}_{33} \mathrm{C}^{2}
\end{gathered}
$$

... where $\mathrm{Y}$ is the dependent variable (diesel degradation $\%)$; A, B, and C are the levels of the independent variables; $\mathrm{b}_{0}$ is regression coefficient at the center point; $b_{1}, b_{2}$, and $\mathrm{b}_{3}$ are linear coefficients; $\mathrm{b}_{12}, \mathrm{~b}_{13}$, and $\mathrm{b}_{23}$ are the secondorder interaction coefficients; and $b_{11}, b_{22}$, and $b_{33}$ are quadratic coefficients. The values of the coefficients were calculated using Microcal Origin 46.1 software and the optimum concentrations were predicted using Microsoft Excel 2007. The quality of the fit of the polynomial model equation was expressed by coefficient of determination $\mathrm{R}^{2}$. The optimal value of diesel degradation was estimated using the solver function of Microsoft Excel.

Three-dimensional graphical representations were also constructed using Statistica 7 software to reflect the effects as well as the interactions of independent variables on the objective.

\section{Biodegradation of Diesel in Soil Sample}

The previous experiments were concerned with biodegradation of diesel in liquid medium and the present experiment is aimed to biodegrade the diesel in soil. This was done using hydrocarbon-free soil, tested using GC, sterilized by autoclaving, and dried at $70^{\circ} \mathrm{C}$ overnight. $40 \mathrm{~g}$ of the sterile soil was polluted by $5 \mathrm{~mL}$ of sterile diesel, roughly homogenized and moistened by $24 \mathrm{~mL}(60 \%$ of its water holding capacity) of nutrient solution of the best culture conditions after RSM. The soil was inoculated by the fungal consortium $\left(3.2 \times 10^{6}\right.$ spores $\left./ \mathrm{mL}, 1: 1\right)$ and the flasks incubated at $30^{\circ} \mathrm{C}$ for 35 days and passively aerated for 15 min under sterile conditions every three days. After fermentation the residual diesel was extracted by n-hexane $85 \%$ and the extract was estimated by GC to determine the residual diesel [30].

\section{Results and Discussion}

\section{Biodegradation of Diesel by Fungal Isolates}

The results indicated that $A$. ustus and A. alternata had the highest degradation percentages (100 and $98.6 \%$, respectively), while $A$. niger showed the lowest degradation activity (92\%), and A. flavus, A. fumigatus, and Rhizopus rhizodopodiformis showed high degradation efficiency of more than $97 \%$. However, the tested Penicillium spp. showed less than $96 \%$ degradation. The same isolates were used to degrade kerosene and it was found that $A$. flavus had the highest degrading ability (96.31\%), followed by A.niger (90.33\%), while the remaining fungi were with lower activities [15]. These results confirm that the biodegradation process depend on the type of hydrocarbon, the genus, species, and may be the strain of the fungus, as well as on nutritional and fermentation conditions.

Time Course Biodegradation of 1\% Diesel Fuel by $A$.ustus and A. alternata

The data in Figs 1, 2 indicate that as the fermentation period extended from three to seven days, the degradation capacity of diesel fuel increased by more than $87.8 \%$ for 
both molds. Within the first four days of fermentation little degradation capacity (less than 29\%) was recorded. While the fifth and sixth days represent higher capacities, ranging between about 62 to $84 \%$ for both molds. However, the seventh day of fermentation represented the best incubation period for complete biodegradation by $A$. ustus and the eighth day for A. alternata. Complete degradation of diesel with lower degradation rate $(12 \%)$ was recorded as the fermentation period was extended to the eighth day. These findings can be explained on the basis that composition of diesel fuel (approximately

a)

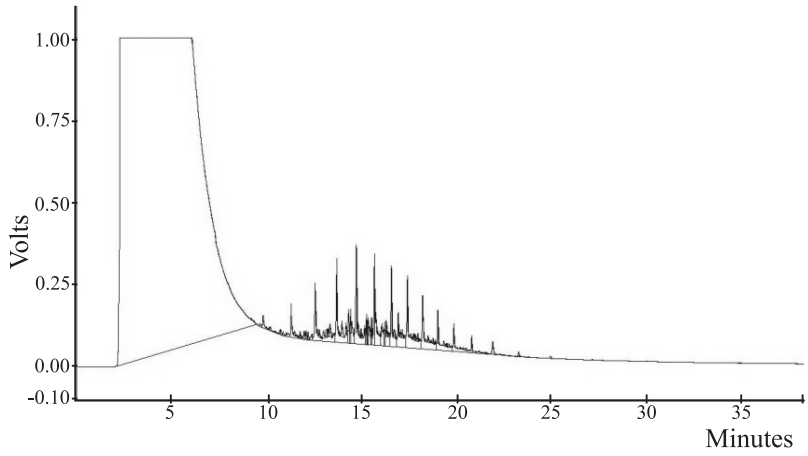

b)

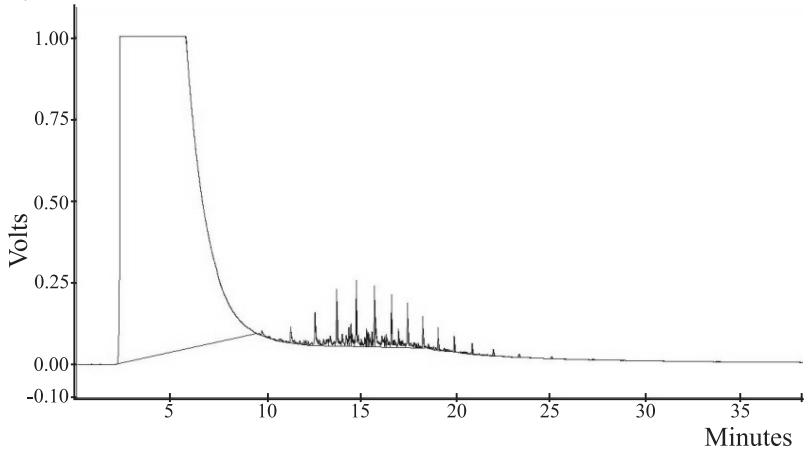

c)

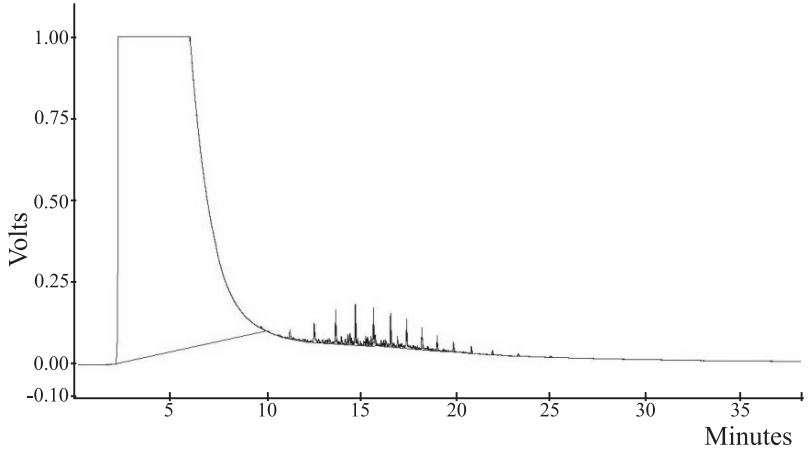

Fig. 1. Biodegradation of $0.5 \mathrm{~mL} \mathrm{DF} / 50 \mathrm{~mL}$ medium by A. ustus a) after 3 days of fermentation

b) after 4 days of fermentation

c) after 5 days of fermentation

d) after 6 days of fermentation

e) after 7 days of fermentation

f) after 8 days of fermentation from $\mathrm{C}_{9}$ to $\mathrm{C}_{20}$ ) is approximately $30 \%$ alkanes, $45 \%$ cyclic alkanes, and $24 \%$ aromatics [31]. So, A. ustus and A. alternata firstly degraded and assimilated the simpler fraction of alkanes and cyclic alkanes that appeared in the lower degradation \% after four days, and for growth and production of hydrolyzing enzymes that enable the fungus to degrade the more complex fractions of diesel after days five and six of fermentation (high degradation from 62 to $82 \%$ ). It was reported that the complex aromatic fractions of hydrocarbons are more toxic to the organisms than the aliphatic fractions $[15,32]$. It was

d)

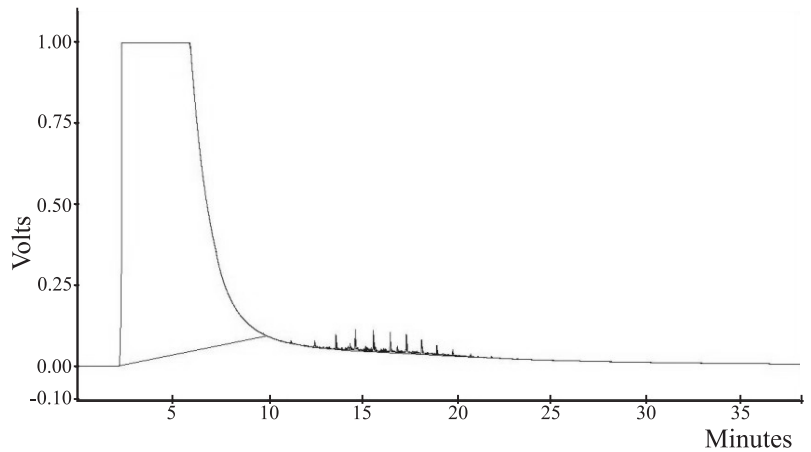

e)

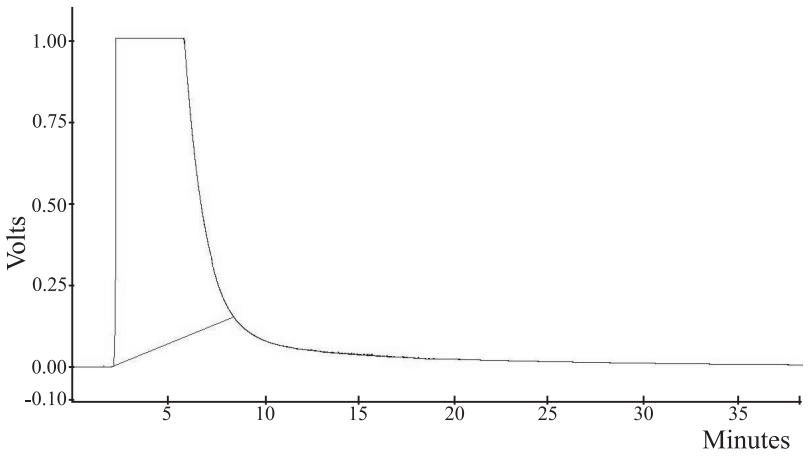

f)

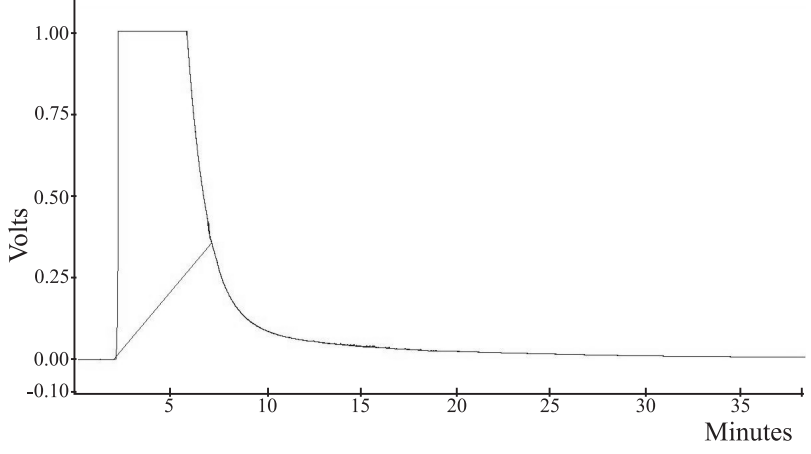


also indicated that simple diesel fractions (alkanes and aromatics) were firstly degraded followed by the complex fractions [33].

\section{Effects of Different Concentrations of Diesel Fuel}

The results indicated that as the diesel fuel concentration increased from 1 to $6 \%(\mathrm{v} / \mathrm{v})$, the degradation activity decreased by about $25 \%$ for A. ustus and $22.9 \%$ for

a)

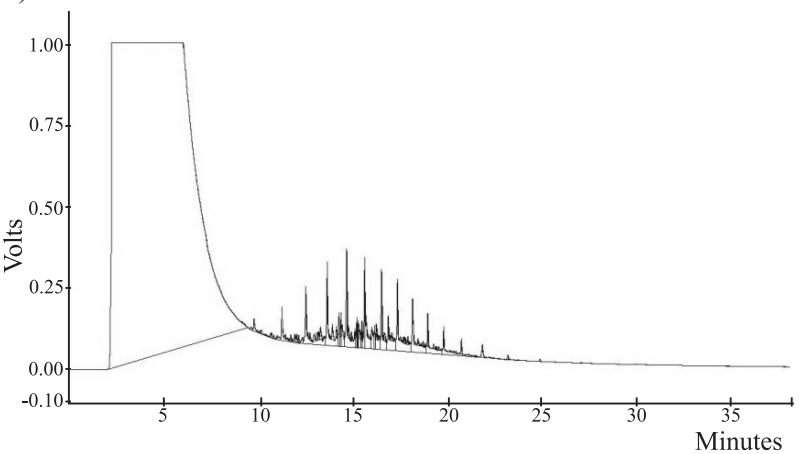

b)

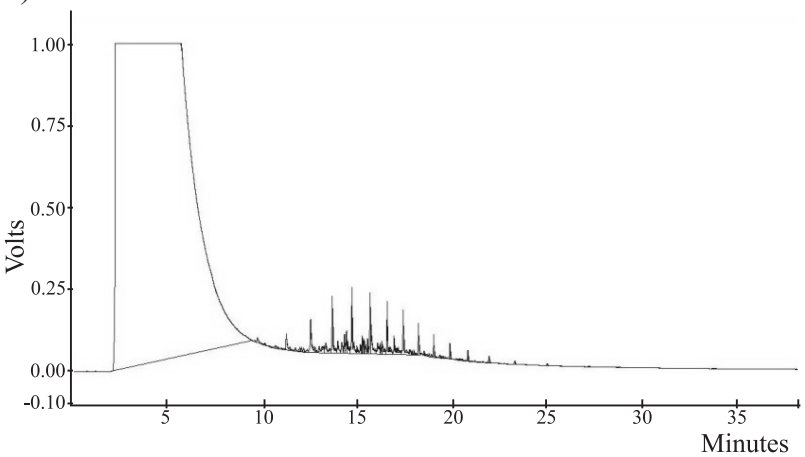

c)

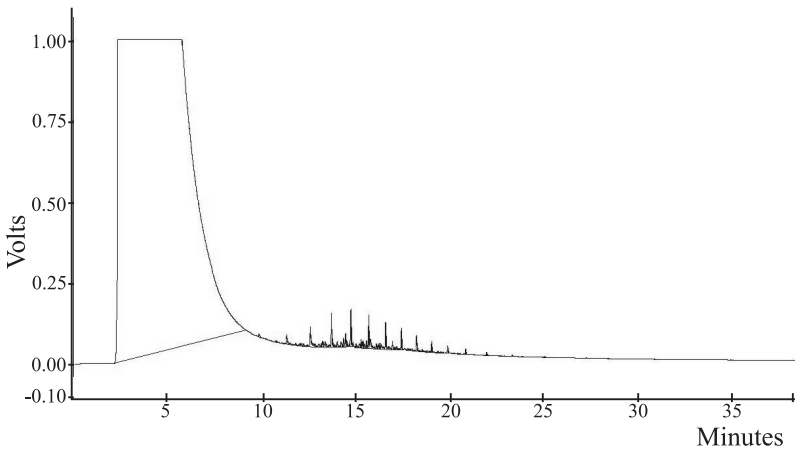

A. alternata. On the other hand, the degradation rate (mL/day) was increased by more than 4.5 -fold for both molds after seven days of incubation. This means that the fermentation conditions stimulated productivity and/or activity of diesel fuel-hydrolyzing enzymes.

However, on the basis of the degraded diesel fuel per day, the two tested fungi (A. ustus and A. alternata) are more economically efficient in the degradation of higher levels of diesel. The results also proved that $A$. alternata is more efficient in degrading the higher concentrations of diesel fuel $(6 \%, \mathrm{v} / \mathrm{v})$ than $A$. ustus.

d)

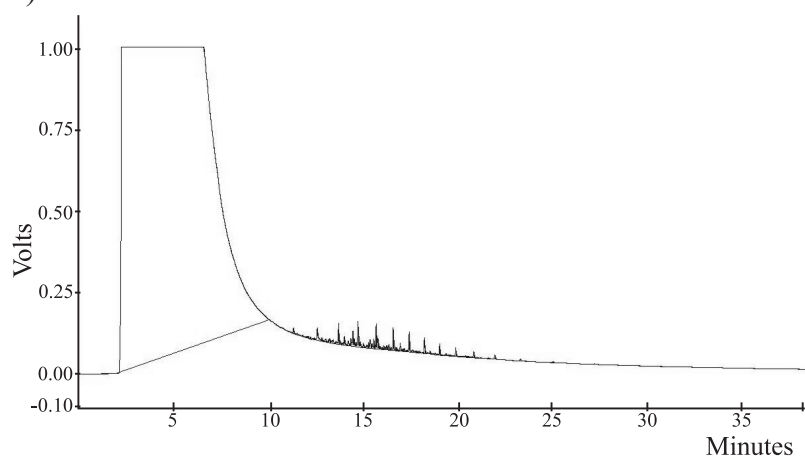

e)

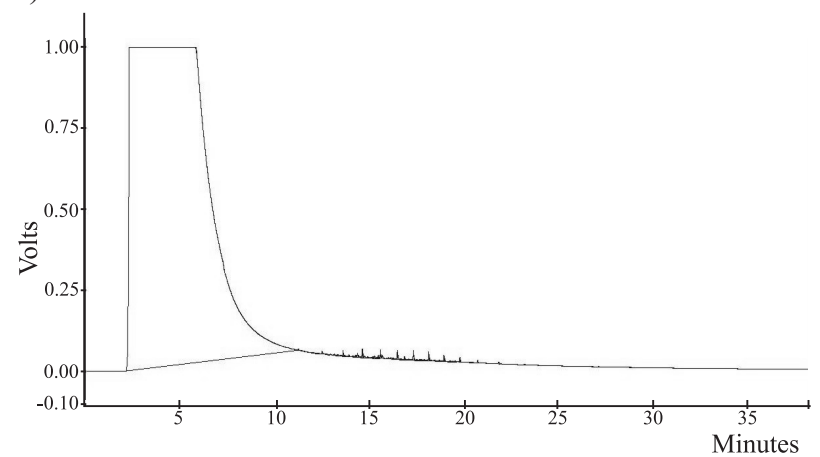

f)

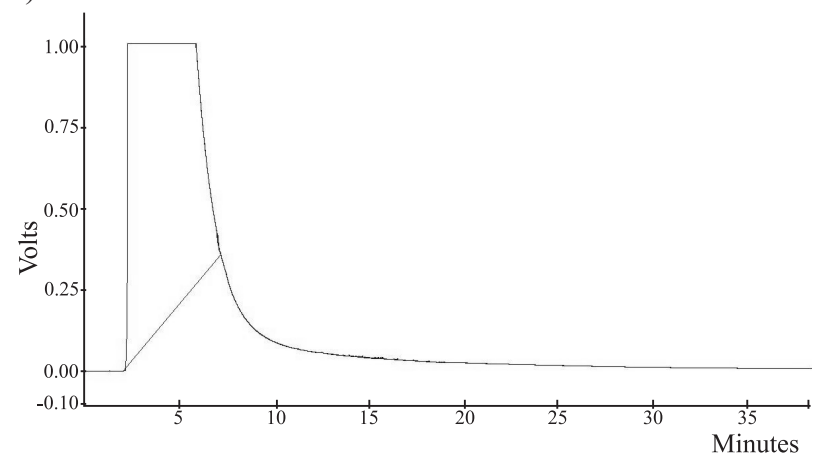

Fig. 2. Biodegradation of $0.5 \mathrm{~mL} \mathrm{DF} / 50 \mathrm{~mL}$ medium by A. alternata a) after 3 days of fermentation b)after 4 days of fermentation c) after 5 days of fermentation

d) after 6 days of fermentation

e) after 7days of fermentation

f) after 8 days of fermentation 


\section{Biodegradation of Different Concentrations of Diesel Fuel by Fungal Consortium with Different Spore Numbers}

The results indicated that biodegradation was considerably enhanced upon using fungal consortium. Thus, $3 \mathrm{~mL}$ diesel was biodegraded at $84.35 \%$ as compared to $76 \%$ by $A$. alternata monoculture at the same inoculums size of monoculture, $1.6 \times 10^{6}$ spores. On the other hand, the same inoculum size was also efficiently able to biodegrade about 82.1 of $4 \mathrm{ml}$ diesel fuel. All the tested diesel fuel levels up to $4 \mathrm{ml}$ showed more than $90 \%$ biodegradation efficiency upon using $1.6 \times 10^{6}$ mixed culture inoculum size. As the inoculum sizes increased from 1.6 to $3.2 \times 10^{6}$ spores, the biodegradation activity increased noticeably, where all the tested diesel fuel levels had been degraded by percentages more than $93 \%$.

The calculation of the average of degradation (\%) of each treatment was about 87.45 , for monoculture $(1.6$ $\mathrm{x} 10^{6} \mathrm{spore} / \mathrm{mL}$ ) and $90.39,95.65$, and $97.73 \%$ for mixed culture of $1.6,2.4$, and $3.2 \times 10^{6}$ spores, respectively. This finding indicates that the mixed culture $\left(1.6 \times 10^{6}\right.$ spores $)$ showed biodegradation increase of about $3.4 \%$ more than monoculture. While doubling the spore numbers in mixed culture technique increased the biodegradation activity by more than $8 \%$, and the fungal consortium can efficiently biodegrade as much as $4 \mathrm{~mL}$ diesel fuel $/ 50 \mathrm{~mL}$ medium. So the results confirmed the efficiency of mixed culture technique in biodegradation of diesel. So the results confirmed higher efficiency of mixed culture technique in biodegradation of diesel fuel in comparison to monoculture technique and spore numbers, as the source of degrading enzymes are significantly enhanced in the biodegradation process.

\section{Effect of Different Levels of the Tween 80 Surfactant on Diesel Biodegradation}

The results indicated that broth medium omitted from tween 80 was not in the favor of degradation of $4 \mathrm{~mL}$ diesel fuel, and only $43.3 \%$ biodegradation was estimated, while the addition of $0.8 \mathrm{~mL}$ tween 80 resulted in about 2.2-fold increase. As the level of tween 80 increased from 0.8 to $3.0 \mathrm{~mL} / 50 \mathrm{~mL}$ medium, little increases of biodegradation activities were recorded and did not exceed $1.92 \%$. While at $6 \%(\mathrm{v} / \mathrm{v})$ tween 80 gave the highest degradation $\%$ and degradation rate $(95.4 \%$ and $0.55 \mathrm{~mL} /$ day, respectively). Some reports indicate that using surfactant such as tween 80 will enhance and influence the biodegradation of oil because it can emulsify hydrocarbons, thus enhancing their solubility in water. This is achieved by decreasing interfacial tension and increasing the displacement of oily substance from soil particles [5, 6, 34].

\section{Screening of Important Variables using Plackett-Burman Design}

The data depicted in Table 1 indicated a wide variation in diesel fuel biodegradation, from 82.6 to $98.6 \%$ in the 10 trials. The variation suggested that process optimization
77.566

79.516

81.465

83.414

85.364

87.313

89.262

91.212

93.161

95.11

above

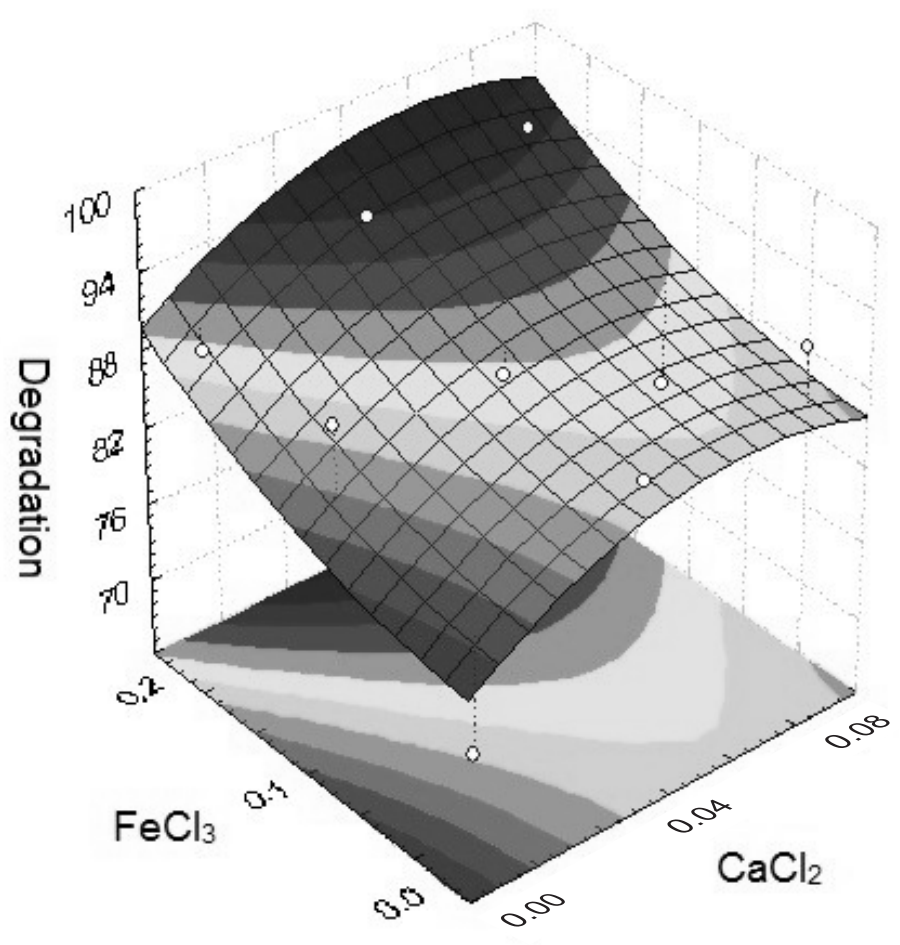

Fig. 3. The interaction of $\mathrm{CaCl}_{2}$ with $\mathrm{FeCl}_{3}$ level. 
was important for improving the biodegradation efficiency. The main effect, analysis of the regression coefficients and the $t$-values of seven factors (Table 3 ), indicated that the most significant three factors on diesel degradation were $\mathrm{FeCl}_{3},\left(\mathrm{NH}_{4}\right)_{2} \mathrm{HPO}_{4}$, and $\mathrm{CaCl}_{2}$. The predicted medium composition and culture conditions to be near optimum, which resulted from Plackett-Burman design was $[\mathrm{g} / \mathrm{L}]: \mathrm{MgSO}_{4} .7 \mathrm{H}_{2} \mathrm{O}, 0.4 ; \mathrm{CaCl}_{2}, 0.06 ; \mathrm{KH}_{2} \mathrm{PO}_{4}, 0.5$; $\left(\mathrm{NH}_{4}\right)_{2} \mathrm{HPO}_{4}, 3.0 ; \mathrm{KNO}_{3}, 2.0 ; \mathrm{FeCl}_{3}, 0.02$ and $25 \mathrm{~mL}$ medium $/ 250 \mathrm{~mL}$ Erlenmeyer flask; i.e., $\mathrm{CaCl}_{2}$ increased from 0.04 to $0.06,\left(\mathrm{NH}_{4}\right)_{2} \mathrm{HPO}_{4}$ from 2.0 to 3.0, and $\mathrm{FeCl}_{3}$ from 0.01 to $0.02(\mathrm{~g} / \mathrm{L})$. Inoculum size $1 \mathrm{ml}$ of $3.2 \times 10^{6}$

70.505

72.489

74.473

76.457

78.441

80.425

82.409

84.393

86.377

88.361

above

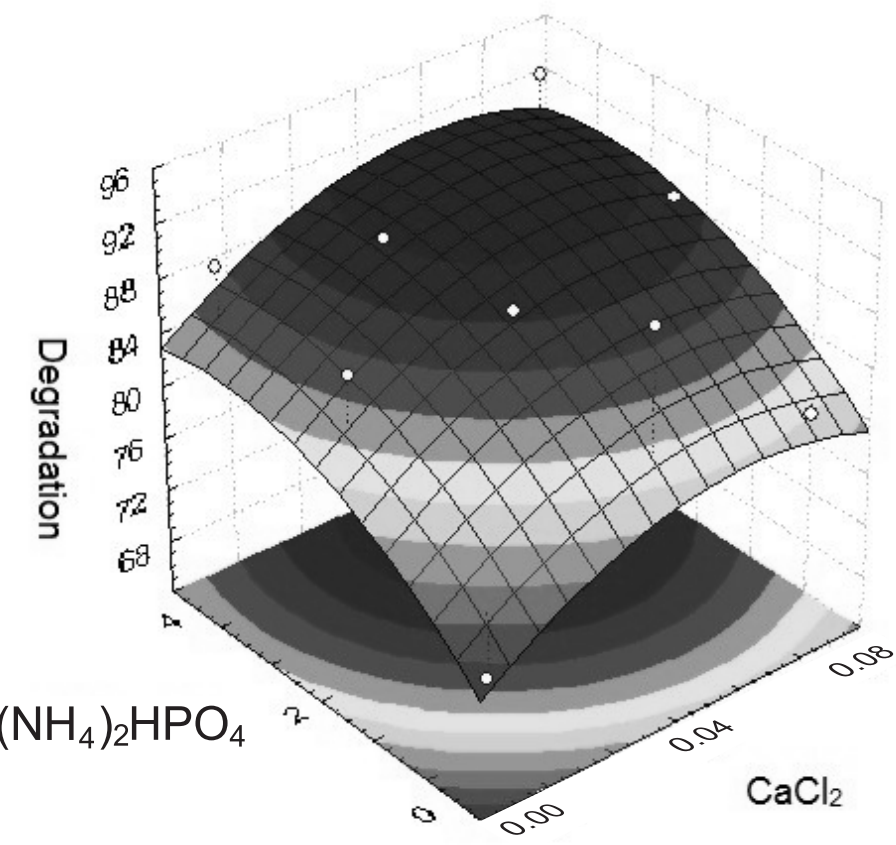

Fig. 4. The interaction of $\mathrm{CaCl}_{2}$ with $\left(\mathrm{NH}_{4}\right)_{2} \mathrm{HPO}_{4}$ Level.

76.146

78.357

80.568

82.778

84.989

87.2

89.41

91.621

93.832

96.042

above

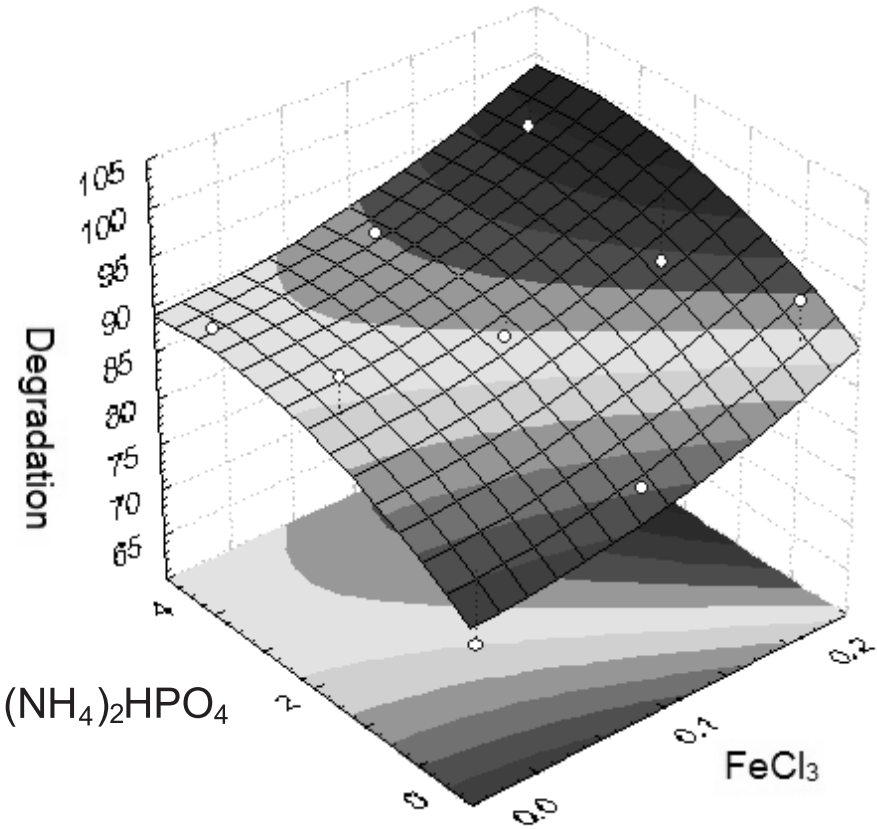

Fig. 5. The interaction of $\left(\mathrm{NH}_{4}\right)_{2} \mathrm{HPO}_{4}$ with $\mathrm{FeCl}_{3}$ level. 
Table 3. Statistical analysis of the Plackett-Burman experimental design.

\begin{tabular}{|c|c|c|c|}
\hline Variable & Main effect [\%] & $t$-value & $\begin{array}{c}\text { Regression } \\
\text { coefficient }\end{array}$ \\
\hline $\mathrm{NH}$ & -5.425 & -1.52 & -10.528 \\
\hline $\mathrm{CC}$ & 4 & 1.04 & 0.389 \\
\hline $\mathrm{KP}$ & -1.425 & -0.34 & -0.139 \\
\hline $\mathrm{MS}$ & 0.45 & 0.11 & 0.044 \\
\hline $\mathrm{KN}$ & -3.75 & -0.96 & -0.365 \\
\hline $\mathrm{FC}$ & $6.375^{*}$ & 1.94 & 0.62 \\
\hline $\mathrm{MV}$ & -1.8 & -0.44 & -0.175 \\
\hline
\end{tabular}

Significant at $5 \%$ level, $\mathrm{R}^{2}=1$.

spores of fungal consortium (A. ustus and A. alternata, $1: 1)$ and incubated under shaking $(150 \mathrm{rpm})$ at $30^{\circ} \mathrm{C}$ for $168 \mathrm{~h}$. These results revealed the importance of nutrients and aeration $(25 \mathrm{~mL} / 250 \mathrm{~mL}$ Erlenmeyer flask at shaking rate of $150 \mathrm{rpm})$. The crucial role of aeration and nutrients in the hydrocarbons was indicated [33].

A confirmatory experiment was conducted to verify the preoptimized medium from Plackett-Burman design. The results of the confirmatory test are congruent with that of the predicted, where $8 \%$ of diesel fuel was completely degraded after $168 \mathrm{~h}$ of fermentation. This indicates the validity and efficiency of the Plackett-Burman design.

\section{Optimizing by RSM}

In order to approach the optimum response region of diesel fuel degradation, the significant independents variables $\left(\mathrm{CaCl}_{2}, \mathrm{FeCl}_{3}\right.$ and $\left.\left(\mathrm{NH}_{4}\right)_{2} \mathrm{HPO}_{4}\right)$ were further explored by applying RSM, each at three levels according to Box-Behnken (1960) to study the interactions between them and also to determine their optimal levels. The design matrix of the coded variables together with the experimental results of diesel fuel degradation are represented in Table 2. The optimal levels of the three levels of the examined independent variables as predicted from the model (trial 9) were (g/L) $\mathrm{CaCl}_{2}, 0.08 ; \mathrm{FeCl}_{3} 0.02$ and $\left(\mathrm{NH}_{4}\right)_{2} \mathrm{HPO}_{4}, 4.0$. At these conditions $4 \mathrm{~mL}$ diesel $125 \mathrm{~mL}$ medium $(16 \%$, v/v) were completely degraded with a rate of $0.57 \mathrm{~mL} /$ day after $168 \mathrm{~h}$ of fermentation. Threedimensional graphical representations of the regression model, called the response surface plots, are presented in Figs 3, 4, and 5. Each response surface plot represented the effect of two independent variables, holding the other variable at zero level. The predicted levels of the three variables $\left(\mathrm{CaCl}_{2}, \mathrm{FeCl}_{3}\right.$ and $\left.\left(\mathrm{NH}_{4}\right)_{2} \mathrm{HPO}_{4}\right)$ to be optimum for $100 \%$ diesel fuel degradation from BoxBehnken design were (g/L) $\mathrm{CaCl}_{2}, 0.08 ; \mathrm{FeCl}_{3}, 0.02$, and $\left(\mathrm{NH}_{4}\right)_{2} \mathrm{HPO}_{4}, 4.0$, which led to $100 \%$ degradation of diesel fuel after $168 \mathrm{~h}$ of fermentation in $25 \mathrm{~mL}$ of medium/ $250 \mathrm{~mL}$ flask. According to this model and PlackettBurman experimental results, an optimum response (diesel fuel biodegradation) is predicted with the following medium composition $(\mathrm{g} / \mathrm{L}): \mathrm{MgSO}_{4} \cdot 7 \mathrm{H}_{2} \mathrm{O}$, 0.4; $\mathrm{CaCl}_{2}, 0.04 ; \mathrm{KH}_{2} \mathrm{PO}_{4}, 0.5 ;\left(\mathrm{NH}_{4}\right)_{2} \mathrm{HPO}_{4}, 2.0 ; \mathrm{KNO}_{3}$, 2.0; $\mathrm{FeCl}_{3}, 0.01$ and $25 \mathrm{~mL}$ medium/250 mL Erlenmeyer flask. So the levels of $\mathrm{CaCl}_{2},\left(\mathrm{NH}_{4}\right)_{2} \mathrm{HPO}_{4}$, and $\mathrm{FeCl}_{3}$ were reduced from $0.08,4.0$, and 0.02 to the previous concentrations. A confirmatory experiment was done to verify the above-predicted conditions. The results of the confirmatory test are congruent with that of the predicted, where $16 \%$ of diesel fuel was completely degraded after $168 \mathrm{~h}$ of fermentation. Therefore, response surface optimization could be successfully used to evaluate the performance in diesel fuel biodegradation and achieve a higher rate of its degradation in less medium volume at $168 \mathrm{~h}$ of fermentation time. The similarity of the predicted and observed results confirms the validity, accuracy, and applicability of the statistical designs in optimization of bioprocesses [16, 35].

\section{Biodegradation of Diesel Fuel in Soil Sample}

The results indicated that the diesel fuel-polluted soil $(12.5 \%, \mathrm{v} / \mathrm{w})$ was completely free from any diesel contamination after 35 days. So the fungal consortium could completely biodegrade the diesel contaminant. These findings confirmed the high efficiency of mixed culture of $A$. ustus and A. alternata under the optimized conditions to degrade diesel fuel either in water or soil. It was indicated that the diesel biodegradation efficiency in the soil by microbial consortium was $85 \%$ after 76 days of treatment and the process depends on the soil characteristics and the environmental conditions required by the microorganisms [33].

\section{Conclusion}

To the best of our knowledge, this was the first report applying statistical experimental design to optimize diesel fuel biodegradation by mixed culture of $A$. ustus and A. alternata. Results suggested that statistical optimum strategy was an effective tool for optimization process parameter on diesel fuel degradation efficiency by fungal consortia. Optimal conditions obtained in this work laid out a strong foundation for further use of these organisms in the treatment of diesel contamination in soil environment.

\section{References}

1. CHAUDHRY S., LUHACH J., SHARMA V., SHARMA C. Assessment of diesel degrading potential of fungal isolates from sludge contaminated soil of petroleum refinery, Haryana. Res.J. Microbiol. 7 [3], 182, 2012.

2. MALIK Z.A., AHMED S. Degradation of petroleum hydrocarbons by oil field isolated bacterial consortium. Afr. J. Biotechnol. 11 [3], 650, 2012.

3. ABIOYE O.P., AGAMUTHU P., ABDUL AZIZ A.R. Biodegradation of used motor oil in soil using organic waste 
amendments. Biotechnol. Res. Inter. ID 587041. 8 pages, 2012.

4. THAPA B., AJAY-KUMAR K.C., GHIMIRE A. A review on bioremediation of petroleum hydrocarbon contaminants in soil. Kathmandu Univ. J. Sci. Engin. Technol. 8 [1], 164, 2012.

5. VILCHES A.P., BYLUND D., JONSSON A. Enhanced natural biodegradation of diesel fuel contaminants in soil by addition of whey and nutrients. Linnaeus ECO-TECH, 10, November 22-24.2010, Kalmar, Sweden, 2010.

6. PARREIRA A.G., TOTOLA M.R., JHAM G.N., DA SILVA S.L., BORGES A.C. Microbial bioremediation of aromatic compounds in a soil contaminated with gasohol. British Biotechnol. J. 1 [2], 18, 2011.

7. PRAKASH B., IRFAN M. Pseudomonas aeruginosa is present in crude oil contaminated sites of Barmer Region [India]. J. Bioremed. Biodeg. 2 [5], 129.doi:10.4172/21556199.1000129.2 pages, 2011.

8. HIDAYAT A., TACHIBANA S. Biodegradation of aliphatic hydrocarbon in three types of crude oil by Fusarium sp. F092 under stress with artificial sea water. J. Environ. Sci. Technol. 5 [1], 64, 2012.

9. DAS N., CHANDRAN P. Microbial degradation of petroleum hydrocarbon contaminants: An overview. Biotechnol. Res. Inter. Article ID 941810, 13 pages, 2011.

10. KUMARI M., ABRAHAM J. Biodegradation of diesel oil using yeast Rhodosporidium toruloides. Res. J. Environ. Toxic. 5 [6], 369, 2011.

11. JUCKPECH K., PINYAKONG O., RERNGSAMRAN P. Degradation of polycyclic aromatic hydrocarbons by newly isolated Curvularia sp. F18m Lentinus sp. S5 and Phanerochaete sp. T20. Science Asia. 38,147, 2012.

12. PRATHEESH P.T., JAYACHANDRAN K. Biodegradation of toluene hydrocarbon by a Pseudomonas sp. isolated from gasoline contaminated soil. Inter. J. Plant Animal Environ. Sci. IJPAES. 2 [3], 210, 2012.

13. JYOTHI K., BABU K.S., CLARA N.K., KASHYAP A. Identification and isolation of hydrocarbon degrading bacteria by molecular characterization. Helix. 2, 105, 2012.

14. MARTIN Y.B., ACOSTA S., SANCHEZ A., TOLEDO A., GONZALEZ F., GARCIA R.M. Study and isolation of aerobic hydrocarbon-degrading bacteria from Cuban shorelines. Biotechnologia Aplicada. 29, 80, 2012.

15. GHANEM K.M., AL-GARNI S.M., ALHOMODI A.F. Biodegradation of kerosene by Asepergillus flavus using statistical experimental designs. Bioremediation Journal. 19, 69, 2015.

16. GHANEM K.M., AL-FASSI F.A., AL-HAZMI N.M. Optimization of chloroxylenol degradation by Aspergillus niger using Plackett-Burman design and response surface methodology. Romanian Biotechnological Letters. 18 [1], 7983, 2013

17. OKERENTUGBA P.B.O., EZERONYE O.B.U. Petroleum degrading potentials of single and mixed microbial cultures isolated from rivers and refinery effluent in Nigeria. Afr. J. of Biotechnol. 2 [9], 288, 2003.

18. FREY D., OLDFIELD R.J., BRIDGER R.C. Color atlas of pathogenic fungi, printed by Smeets-Weert, Holland. 92, 1979.

19. WATANABE T. Pictorial atlas of soil and seed fungi. $2^{\text {nd }} \mathrm{Ed}$. CRC Press: 190, 2002.

20. CBS. Central Bureauvoor Scimmelcultures, identification common species of Aspergillus, Available at: www.cbs. knaw.nl, 2006.
21. OBIRE O., ANUYANWU E.C., OKIGBO R.N. Saprophytic and crude oil degradation fungi from cow dung and poultry dropping as bioremediating agents. J. Agricultural Technol. 4 [2], 81, 2009.

22. BUSHNELL L.D., HAAS H.F. In: Mandari,T., Lin, J. (2007). Isolation and characterization of engine oil degrading indigenous microorganisms in Kwazulu-Natal South Africa. In: Afr. J. Biotechnol. 6 [1], 23, 1941.

23. GEORGE-OKAFOR U., TASIE F., OKAFOR F.M. Hydrocarbon degradation potentials of indigenous fungal isolates from petroleum contaminated soils. J. Physical Nat. Sci. 3 [1], 1, 2009.

24. MUKRED A.M., HAMID A.A., HAMZAH A., WAN YUSOFF W. Development of three bacteria consortium for the bioremediation of crude petroleum-oil in contaminated water. Online J. Biological Sci. 8 [4], 73, 2008.

25. KURAN P., TROG J., NOVAKOVA J., PILAROVA V., DANOVA P., PAVLORKOVA J., KOZLER J., NOVAK F., POPELKA J. Biodegradation of spilled diesel fuel in agricultural soil: Effect of humates, zeolite, and bioaugmentation. The Scientific World J. 2014, Article ID 642427, 8, 2014.

26. BENTO F.M., CAMARGO F.A.O., OKEKE B.C., FRANKENBERGER W.T. Comparative bioremediation of soils contaminated with diesel oil by natural attenuation, biostimulation and bioaugmentation. Biores. Technol. 96, 1049, 2005.

27. STANBURY P.F., WHITAKER A., HALL S.J. Media for industrial fermentations. In: Principles of fermentation technology. Pergamon Press, Oxford. 93, 1986.

28. PLACKETT R.L., BURMAN J.P. The design of optimum multifactorial experiments. Biometrica. 33, 305, 1946.

29. BOX G.E.P., BEHNKEN D.W. Some new three level designs for the study of quantitative variables. Technometrics. $\mathbf{2}$, 455, 1960.

30. MANCERA-LOPEZ M.E., GARCIA F.E., GOMEZ B.C., VAZQUEZ R.R., CASTANEDA G.S., CORTES J.B. Bioremediation of an aged hydrocarbon-contaminated soil by a combined system of biostimulation-bioaugmentation with filamentous fungi. Inter. Biodeter. Biodeg. 61, 151, 2008.

31. MOLITERNI E., JIMENEZ TUSSET R.G., VILLAR RAYO M., RODRIGUEZ L., FERNANDEZ F.J., VILLASENOR J. Kinetics of biodegradation of diesel fuel by enriched microbial consortia from polluted soils. Inter. J. Environ. Sci. Technol (IJEST). 9 (4), 749, 2012.

32. BACOSA H., SUTO K., INOUE C. Preferential degradation of aromatic hydrocarbons in kerosene by a microbial consortium. Inter. Biodeter. Biodeg, 64, 702, 2010.

33. CHEMLAL R., ABDI N., LOUNICI H., DROUICH N., PAUSS A., MAMERI N. Modeling and qualitative study of diesel biodegradation using biopile process in sandy soil. Int. Biodeter. Biodeg. 78, 43, 2013.

34. CAMPOS-PINEDA M., ACUNA-ASKAR K., MARTINEZGUEL J.A., MAS-TREVINO M., TIJERINA-MENCHACA R., MARTINEZ L.M., VIDEA M., PARRA-SALDIVAR R. Time and cost efficient biodegradation of diesel in a continuous-up flow packed bed biofilm reactor and effect of surfactant GAELE. J. Chem. Technol. Biotechnol. DOI 10.1002/jctb.3736, 10, 2011.

35. ZHOU J., YU X., DING C., WANG Z., ZHOU Q., PAO H., CAI W. Optimization of phenol degradation by Candida tropicalis Z-04 using Plackett-Burman design and response surface methodology. J. Environ. Sci. 23 [1], 22, 2011. 